\title{
DIMENSI RELIGIUSITAS AGENSI PENDIDIKAN POLITIK PARTAI NASDEM JAWA TIMUR
}

\author{
Luluk Mashluchah \\ Universitas Islam Jember, Jember, Indonesia \\ E-mail: mashluchahluluk@gmail.com
}

\begin{abstract}
Religious discourse in political praxis always attracts the attention of many experts. Some of them consider that the use of religion represents more pragmatic interest of political parties for stimulating voters in general elections. This study argues that the use of religion in political praxis is not merely for the pragmatic purposes of the party, but also for the party's idealistic goals. This is the reason that makes the implementation of political education important for integrating religious dimensions. NasDem Party of East Java is known for its concern in promoting its ideal image as a nationalist-religious party. In order to realize its image and political vision, NasDem carries religion-based politics in its political education. This article aims to study issues such as how religious dimensions are contained in political education and how the orientasions of the agency of political party are. This article found an important finding that there were two dimensions in the implementation of political education, namely the ritualsymbolic and substantive religious dimensions. The orientation of symbolic religious dimension is to strengthen the faith and the creation of nationalityreligious intergated understanding, while the substantive dimension is oriented to shape a humanist-religious consciousness and God's mandate in the political role.
\end{abstract}

Keywords: Religious dimensions; structuration; cadres; political parties.

\section{Pendahuluan}

Diskursus isu relasi "agama" dan "politik" selalu menarik untuk dikaji. Isu agama telah menjadi religio-political power, atau meminjam istilah Bourdieu "modal kultural-simbolik" (symbolic- 
cultural capital). ${ }^{1}$ Bagi partai politik, isu agama menjadi legitimasi institusi politiknya dan sekaligus penarik dukungan massa dari kalangan umat beragama. ${ }^{2}$ Dapat dipahami, jika pemanfaatan sumber-sumber keagamaan dalam dunia politik kepartaian berkaitan dengan banyak hal yang tidak saja kompleks, tetapi juga memiliki jalinan relasional yang rumit, saling bersinggungan dan bahkan bertabrakan (kontradiksi). Secara empirik, pemanfaatan agama oleh para politisi, bagaimanapun, tidak bisa dilepaskan dari kepentingan dominasi ataupun pencarian legitimasi. Secara inheren, moralitas para politisi, sekalipun mereka adalah santri, adalah-meminjam bahasa Machiavelli-moralitas berkuasa. Karena itu, penting untuk dikritisi bahwa pemanfaatan agama dalam kepolitikan mereka sarat dengan muatan kepentingan politik praktis. Dalam konteks ini, aspek-aspek moralitas keagamaan yang kerap digaungkan oleh para politisi tidak lebih sebagai instrumen dominasi. $^{3}$

Untuk menciptakan pemahaman bersama, pendidikan politik memiliki fungsi yang penting. Salah satu partai yang melakukan pendidikan politik adalah Partai NasDem Jawa Timur. Meskipun bukanlah partai yang berlatar-belakang agama (dilihat dari asas, tujuan, dan basis massanya), NasDem menghendaki agar kaderkader terdidiknya tidak hanya memiliki karakter nasionalismedemokrat, melainkan juga religius. NasDem berkepentingan untuk meneguhkan citra dirinya sebagai partai nasionalis yang tetap memegang teguh nilai-nilai religius. Kenyataan bahwa masyarakat Indonesia adalah warga negara yang religius membuat pencitraan semacam itu tampak menjadi suatu keniscayaan. Dengan double branding tersebut, NasDem sebagai pendatang baru (new comer) dalam kancah perpolitikan Indonesia pascareformasi, dapat menarik simpati, empati, dan pada akhirnya dukungan dari berbagai kalangan, baik nasionalis maupun religius.

\footnotetext{
${ }^{1}$ Haryatmoko, "Menyingkap Kepalsuan Budaya Penguasa: Landasan Teoritis Gerakan Sosial Menurut Pierre Bourdieu”, Basis, Vol. 52, No. 11-12 (2003).

2 Menurut Berger, secara historis agama merupakan instrumentalitas legitimasi yang tersebar dan efektif, karena agama menghubungkan konstruksi realitas rawan yang empirik dengan realitas purna yang transendental. Peter L. Beger, Langit Suci: Agama sebagai Realitas Sosial, terj. Hartono (Jakarta: LP3ES, 1991), 4243.

3 Niccolo Machiavelli, Sang Penguasa: Surat Seorang Negarawan kepada Pemimpin Republik, terj. C. Woekirsari (Jakarta: Gramedia, 1987), 91-97.
} 
Pada konteks sosial-politik Jawa Timur, agenda pendidikan politik berdimensi religius yang diselenggarakan oleh NasDem tidak bisa dilepaskan dari kenyataan empirik Jawa Timur sebagai daerah santri. Karena itu, agar partai ini bisa diterima oleh sebagian besar warga masyarakat Jawa Timur, maka diperlukan citra partai yang religius pula. Tentu saja, religiusitas yang disematkannya bukanlah religiusitas yang ideologis, melainkan religiusitas yang moderat. Dalam hal ini, religiusitas yang dikonstruksi oleh NasDem berbeda dengan religiusitas partai-partai Islam, seperti PKS dan PPP, dan bahkan religiusitas partai-partai berbasis massa Islam, seperti PKB dan PAN.

Artikel ini bertujuan mengulas dinamika pergulatan NasDem Jawa Timur dalam menyelenggarakan pendidikan politik berdimensi religius bagi kader-kadernya. Sebagai partai sekuler, upaya NasDem dalam membawa dimensi-dimensi keagamaan dalam praksis pendidikan politiknya menjadi isu kajian yang cukup menantang. Artikel ini berargumen bahwa ada hal-hal yang tidak sebatas pragmatis, melainkan juga idealistik yang berada di balik praksis pendidikan politik berdimensi religius yang diselenggarakan NasDem. Alih-alih bertujuan untuk melembagakan praktik dominasi dan pencarian legitimasi, penggunaan sumber-sumber agama dalam praksis pendidikan politik tersebut berorientasi pula untuk mentransmisikan dan mentransformasikan visi ideal kepartaian pada agensi dan strukturnya. Dalam kajian ini, ada tiga isu penting yang akan diungkap, yakni dimensi religiusitas pendidikan, orientasinya dalam pembentukan agensi, dan struktur partai. Guna mendapatkan suatu hasil kajian yang komprahensif, sudut pandang yang akan dipakai adalah teori strukturasi Anthony Giddens. Teori tersebut diharapkan dapat mendalami orientasi pendidikan pada agensi sekaligus struktur partai yang dikaji.

Selain penting, pun belum banyak kajian yang secara komprehensif mengulas persoalan ini. Secara umum, kajian-kajian yang ada lebih banyak mengulas sepak terjang partai dalam perpolitikan praktis (seperti perilaku politik partai), wacana kepolitikan/kekuasaan elite partai, dan sejenisnya. Demikian halnya, kajian-kajian yang menyinggung relasi antara agama dan politik, cenderung mengelaborasi hanya sisi ideologisasi dan politisasi ataupun komodifikasi agama dalam aktivitas perpolitikan praktis. 
Harus diakui bahwa kajian-kajian yang mengulas kaitan antara pendidikan dan politik memang sudah ada, termasuk di dalamnya pendidikan kewarganegaraan (civic education) dan sosialisasi ataupun pendidikan politik (political socialization/education). Namun, belum ditemukan kajian yang mengulas secara komprehensif aspek religiusitas dalam pendidikan politik kepartaian tersebut. Setidaknya terdapat sejumlah penelitian terdahulu yang dapat dijadikan referensi untuk memperkuat argumentasi penulis, yaitu penelitian Redi Panuju ${ }^{4}$ yang hanya berfokus pada peran agama dalam politik; dan juga penelitian Hariyanti ${ }^{5}$ dan Suryanef ${ }^{6}$ yang hanya berbicara satu sudut saja, yakni pendidikan politik NasDem saja, tanpa terfokus pada masuknya nilai religius di dalamnya.

Lebih-lebih, jika dilihat dari teori atau analisis studi yang dipakai, nampaknya tidak ada satu pun kajian terdahulu yang melakukan pendekatan agency dan strukturasi sebagaimana kajian dalam artikel ini. Padahal, untuk menggambarkan realitas kesadaran, tindakan, dan proses pendidikan sebagai upaya strukturasi dunia politik, adalah lebih tepat untuk membaca terlebih dahulu struktur dan agen yang terkait di dalamnya. Tanpa pendekatan strukturasi dan agen, tentu pemahaman secara menyeluruh tidak akan diperoleh. Sebagaimana dipahami, kajian tentang agensi dan strukturasi akan menggambarkan kompleksitas proses pembentukan tindakan sosial-politik kemasyarakatan. Bahkan, dengan pendekatan tersebut, sebuah kesadaran dan nalar pengetahuan yang nantinya dapat membentuk sebuah tindakan akan secara lugas tergambarkan.

\section{Pendidikan Politik NasDem Jawa Timur}

Pada praktiknya, pendidikan politik yang dijalankan NasDem Jawa Timur tidak sebatas berkaitan dengan penyampaian pengetahuan semata (transfer of knowledge) yang bersifat searah, dari pengurus kepada kader dan publik. Menurut sejumlah pengurus,

\footnotetext{
${ }^{4}$ Redi Panuju, "The Politicization of Religion, Ironi of Ideology and Clash of Discourse Approaching 2019 General Election”, Jurnal Penelitian, Vol. 15, No. 1 (2018), 1-14.

5 Hariyanti et al., "The Role of Political Parties in Building Loyalty Women Cadres through Political Education", Proceedings of the Annual Civic Education Converence (ACEC 2018).

${ }^{6}$ Suryanef et al., "Political Education for Female Cadres as an Effort to Gender Equality in Politics", Proceedings of the 1st International Conference on Social Sciences and Interdisciplinary Studies (ICSSIS 2019).
} 
partai memiliki komitmen yang tinggi untuk mengedukasi masyarakat agar mereka memiliki keberdayaan terutama secara politik. Pendidikan NasDem nampak seperti pendidikan politik yang dilakukan pada umumnya. Sebagaimana dimaklumi, pendidikan politik (political education) tidak bisa dilepaskan kaitannya dengan sosialisasi politik (political socialization). ${ }^{7}$ Pada sisi ini, dapat dikatakan bahwa pendidikan politik dilakukan untuk meproklamirkan dan memberikan pemahaman kepada setiap agen agar memahami wawasaan yang ada di NasDem. Melalui pendidikan, diharapkan masyarakat memiliki pengetahuan, pemahaman, dan keterampilan berpolitik, dalam pengertian melaksanakan tugas dan kewajibannya sebagai warga negara. Menurut mereka, proses perpolitikan dan demokrasi tidak akan dapat berjalan dengan baik tanpa keterlibatan partisipatif dari masyarakat. Tidak sebatas dalam pemilihan umum, partisipasi masyarakat sangat dibutuhkan pula dalam proses pembangunan, perumusan kebijakan, dan pengontrolan jalannya kekuasaan.

Selain itu, praksis pendidikan politik NasDem diorientasikan pula pada upaya untuk-pertama-tama dan utama—membekali kader partai agar memiliki pemahaman dan kesadaran terhadap partai politiknya sendiri. Menurut sejumlah pengurus, kader merupakan ujung tombak partai dalam menggerakkan roda partai, organisasi-organisasi yang menjadi sayap partai, dan lembagalembaga pemerintahan. Kader pula yang menjadi aktor penting dalam mempromosikan citra, ide, gagasan, dan agenda politik partai kepada publik. Tanpa kader, partai tidak akan berarti sama sekali karena tidak akan dapat menjalankan aktivitas kepolitikannya. ${ }^{8}$

Selain membekali wawasan kepartaian, pendidikan politik juga berusaha untuk meningkatkan kualitas pengetahuan dan kesadaran kader mengenai persoalan kebangsaan ataupun keindonesiaan. Hal ini penting mengingat muara dari cita-cita luhur setiap partai politik, termasuk NasDem, tidak lain adalah terwujudnya Indonesia yang semakin berdaulat, demokratis, dan sejahtera warga negara-

\footnotetext{
7 Ada pula yang mengatakan bahwa sosialisasi politik sebenarnya juga merupakan doktrin politik yang harus ditanamkan pada setiap anggota partai politik. Ramlan Surbakti, Memahami Ilmu Politik (Jakarta: Grasindo, 2010), 154.

${ }_{8}^{8}$ Effendy Choirie (Korwil ), Wawancara, Minggu, 18 Maret 2017 pukul 08.00 WIB di Surabaya.
} 
nya. Dalam kaitan inilah, materi-materi pendidikan ditekankan pada sejarah perjuangan dan kemerdekaan bangsa, perumusan ideologi Pancasila dan UUD 1945, kebhinnekaan, dan lainnya. Melalui wawasan nasionalisme, setiap kader NasDem diharapkan benar-benar menjadi negarawan-nasionalis (terkait pandangan, sikap, dan perilaku) dalam praksis politiknya. ${ }^{9}$

Dalam pandangan pengurus partai, komitmen terhadap partai dan bangsa merupakan dua hal yang saling berkelindan dan tidak mungkin bisa dipisahkan. Ibarat dua sisi mata uang, satu sisi menampilkan wajah partai dan sisi lainnya menampakkan wajah bangsa. Oleh karena itu, dalam pendidikan politik, keduanya (kepartaian dan keindonesiaan) menjadi materi yang wajib diajarkan tanpa bisa ditawar-tawar. Setidaknya, pandangan semacam ini secara jelas dikemukakan oleh Effendy Choirie, pengurus pusat sekaligus ketua Dewan Pengurus Wilayah (DPW) Partai NasDem 2014-2016. Dalam pernyataannya, ia menyebutkan bahwa mendidik kader pada esensinya adalah:

Mengajarkan tentang lahirnya partai dan siapa yang mendirikan, mengajarkan unsur yang penting dalam ke-NasDem-an; sejarah Partai NasDem, visi-misi, manifesto, garis politik, ideologi. Hal ini adalah dasar yang harus dimiliki oleh kader NasDem. Mengajarkan Negara Kesatuan Republik Indonesia, memiliki ideologi Pancasila, UUD 1945, ini harus betul-betul dipahami. Unsur yang harus dipahami oleh kader adalah sejarah Indonesia; sejarah kemerdekaan Indonesia, sejarah lahirnya Pancasila, memahami budaya bangsa, budaya nusantara. Dengan demikian, NasDem memiliki komitmen, selain komitmen kepartaian, yaitu militansi terhadap partai, juga komitmen kesetiaan kepada negara dan bangsa; mengawal kepada bangsa, toleran, mempertahankan NKRI secara terus-menerus. ${ }^{10}$

Selain itu, pendidikan politik NasDem Jawa Timur diarahkan pula untuk membentuk kader partai yang memiliki sikap dan perilaku politik yang baik. NasDem mengajarkan kepada kaderkadernya agar menjaga murü'ah (kewibawaan atau nama baik) partai dengan tidak melakukan tindakan-tindakan tercela dan melawan hukum, seperti korupsi, kolusi, nepotisme, tindakan asusila, dan

\footnotetext{
9 Observasi pada Sekolah Kader DPD Partai NasDem Kabupaten Sidoarjo di The Sun Hotel, 24 April 2016.

10 Effendy Choirie, Wawancara, Minggu, 18 Maret 2017 pukul 08.00 WIB di Surabaya.
} 
sejenisnya. Sudah menjadi rahasia umum bahwa dunia perpolitikan praktis identik dengan persaingan dan perebutan kekuasaan. ${ }^{11}$ Dengan kata lain, pendidikan politik NasDem harus bukan hanya berkenaan dengan apa yang telah Brownhill jelaskan. ${ }^{12}$ Di dalamnya, harus memuat etika, ketaatan hukum, pengembangan loayalitas dan sebagainya, sehingga orientasinya bukan hanya untuk menjadi politisi ulung, tetapi juga meciptakan negarawan yang luar biasa.

Dalam praktiknya, perebutan kekuasaan oleh para politisi itu, kerap mempertontonkan tindakan-tindakan yang jauh dari kata 'beradab'. Saling sikut antarpartai ataupun politisi dengan menghalalkan berbagai macam cara, merupakan pemandangan yang lumrah dijumpai dalam dunia perpolitikan di Indonesia dewasa ini. Politik yang esensinya merupakan sebuah seni untuk mengelola pemerintahan secara demokratis, dalam kenyataannya masih jauh panggang dari api. Karena itulah, pengurus partai memandang penting untuk mendidik kader-kadernya agar amanah dalam berpolitik. Dengan demikian, dapat dijelaskan bahwa pendidikan politik yang diadakan berorientasi pada pembentukan agensi yang bermutu. Dalam hal ini, bermutu berarti memiliki pengalaman, pengetahuan, loyalitas, dan moralitas, sehingga setiap agen nantinya mampu berkomitmen tinggi dalam menjalankan tugas kepartaiannya.

\section{Varian Pendidikan Politik NasDem}

Ikhtiar para pengurus NasDem Jawa Timur untuk memperkenalkan identitas partai dan mentransmisikan visi, misi, dan manifesto politik partai dalam bingkai keindonesiaan dilakukan melalui saluran pendidikan politik, baik formal, non-formal, dan informal. Pendidikan politik formal diwujudkan dalam bentuk Sekolah Legislatif dan Sekolah Kader, sedangkan non-formal dan informal diaktualisasikan dalam bentuk-bentuk kegiatan seperti

\footnotetext{
11 Muzammil Syafi'i, Wawancara, 13 Maret 2017 di kantor DPRD , Jl. Indrapura Jaya No. 1 Krembangan Selatan, Surabaya. Syafi'i adalah Ketua Fraksi Partai NasDem ; Wakil Ketua Bidang Pemenangan Pemilu DPW Partai NasDem ; sekaligus Kepala Sekolah Legislatif.

12 Robert Brownhill dan Patricia Smart, Political Education (London dan New York: Routledge, 1989), 110.
} 
diskusi, seminar, dialog, perayaan hari-hari besar agama, dan berbagai kegiatan non/informal lainnya. ${ }^{13}$

Achmad Heri, anggota NasDem yang juga anggota DPRD Provinsi Jawa Timur, menjelaskan bahwa jenis pendidikan di NasDem meliputi pendidikan formal, non-formal, dan informal dengan materinya masing-masing. Cermin keagamaan, baik Islam, Kristen, maupun Hindu, tidak harus nampak secara formal. Namun, nilai-nilai spiritualitas agama tetap tercermin dalam tindakan politik partai; tercermin dalam menuangkan perundangundangannya atau peraturan-peraturan daerah, dalam menuangkan anggaran-anggaran yang prorakyat, memperjuangkan anggaran pendidikan dan anggaran terkait dengan penguatan ekonomi kerakyatan UMKM, dan memperjuangkan kebijakan kesehatan yang prorakyat, yaitu kesehatan murah dan terjangkau untuk rakyat. $^{14}$

Bagi kader-kader yang ada di luar sistem, atau mereka yang belum mendapatkan posisi di legislatif dan menjadi pegiat pengurus partai, mereka diberi pelatihan-pelatihan berjenjang, yaitu short course untuk melakukan tugas-tugas kepartaian, seperti halnya Akademi Bela Negara (ABN) yang terdiri dari pemuda-pemuda terdidik lulusan S1 dan minimal D3. Mereka dididik untuk memahami keberadaan, arti dan fungsi partai politik bagi pembangunan bangsa. Selain itu, dalam ABN, mereka juga dibekali pengetahuan dan bekal keterampilan untuk menjadi kader bangsa yang memiliki loyalitas dan kecintaan terhadap NKRI berdasarkan Pancasila dan UUD 1945.

Secara lebih detail gambaran mengenai varian-varian pendidikan politik NasDem, dalam bentuknya yang formal, nonformal dan informal, akan dikemukakan berikut ini.

1. Sekolah Legislatif

Sekolah Legislatif dimaksudkan untuk membentuk kader calon legislatif dan anggota dewan dari NasDem agar memiliki

13 Effendy Choirie, Wawancara, Minggu, 18 Maret 2017 pukul 08.00 WIB di Surabaya.

${ }^{14}$ H. Achmad Heri, Wawancara, 22 Maret 2017 pukul 19.00 WIB, bersamaan dengan kegiatan Rakoornas NasDem di Surabaya. Pria kelahiran Bangkalan Madura ini pernah nyantri di Ponpes Manbaul Ma'arif Denayar Jombang; mantan aktivis Pergerakan Mahasiswa Islam Indonesia (PMII) Komisariat IAIN Surabaya; Ketua Forum Remas Surabaya; pernah menjadi pimpinan pusat IPNU; dan Wakil Ketua Lakpesdam NU. 
pemahaman yang komprehensif mengenai fungsi-fungsi legeslatif sebagai perpanjangan tangan dan lidah rakyat. Kader harus paham dengan tugas-tugas legislasi seperti controlling dan budgeting. Ini tugas kepartaian yang ada di parlemen, selain penguatan internal organisasi. Lebih lanjut, Nico Ainul Yakin mengatakan bahwa pelaksanaan sekolah legislasi tidak lain adalah untuk meningkatkan kinerja anggota dewan dari NasDem dalam melaksanakan tugastugas kedewanan sesuai fungsinya, seperti fungsi kontrol dan penganggaran. Yakin mengatakan:

Ini kan soal teknik, ya masalah teknik ini memang tidak banyak dikuasai oleh anggota dewan yang baru. Selebihnya dari proses yang dilakukan itu, harapan NasDem, anggota dewan Jawa Timur mampu menjadi agen visi dan misi NasDem untuk sampai pada sifat kebijakan jadi melahirkan Undang-Undang, Peraturan Daerah (Perda), biar ada warna di restorasi itu. Itu harapan. Sementara kurikulum dan matrikulasinya belum ada, tetapi dalam setiap keseharian kita, katakan yang informal, misalnya menugaskan kader-kader mengikuti pelatihan-pelatihan, kemudian mengirim duta-duta NasDem untuk mengikuti sekolah politik muda, itu kita kirim, seperti yang ke Jogja. Sementara yang non-formal kita dalam keseharian menjadi kepanitian dalam suatu kegiatan. ${ }^{15}$

DPW NasDem Jawa Timur mengadakan Sekolah Legislatif yang diintegrasikan dengan kegiatan Sekolah Kader di Hotel Savana, Malang, pada 12-14 Juni 2014. Kegiatan tersebut diikuti oleh seluruh pengurus DPW dan DPD Partai NasDem dan anggota DPRD Partai NasDem se-Jawa Timur. Hadir dalam kegiatan tersebut, yaitu: Korwil, Ketua Fraksi NasDem DPR-RI, Viktor Buntilu Laiskodat; Ketua Fraksi Partai NasDem, Prananda Surya Paloh; Ketua DPP Bidang media dan komunikasi politik, Saur Hutabarat, serta beberapa narasumber lain yang berbicara masalah-masalah kedewanan. ${ }^{16}$

Selain diproyeksikan membekali kader-kader NasDem di parlemen agar mampu dan cakap menjalankan tugas-tugas kedewanan, Sekolah Legislatif ini juga dimaksudkan untuk

15 Nico Ainul Yakin, Wawancara, 9 April 2017 pukul 15.00 WIB di Surabaya. Yakin merupakan mantan aktivis PMII , kepemudaan dan keagamaan NU, dan mantan wartawan.

${ }^{16}$ Berdasarkan hasil observasi pada Sekolah Kader di Hotel Savana, Malang, 1214 Juni 2014. 
membekali anggota dewan dari NasDem agar memiliki karakter restoratif. Karakter restoratif dalam perspektif NasDem adalah memiliki dedikasi dan jiwa memperbaiki, memulihkan, mengembalikan, dan mencerahkan terhadap dinamika bangsa dan negara sesuai dengan cita-cita proklamasi kemerdekaan RI, yang memiliki benang merah dengan nilai-nilai agama dan budaya bangsa yang luhur untuk mencapai tujuan nasional. ${ }^{17}$

2. Sekolah Kader

Setelah Sekolah Legislatif, DPW meresmikan pembukaan Sekolah Kader di kantor NasDem Jawa Timur pada 2 Februari 2015. Kegiatan ini diikuti oleh seluruh pengurus DPW dan utusan dari DPD Partai NasDem se-Jawa Timur. Karena masih awal dan sistemnya belum terbentuk, maka Sekolah Kader pada tahap ini hanya berkisar pada materi ke-NasDem-an. Yang menjadi narasumber pada kegiatan tersebut adalah ketua DPW, Effendy Choirie, Korwil Sri Sajekti Sudjunadi, dan Enggartyasto Lukita, Ketua Bappilu DPP Partai NasDem (sekarang Menteri Perdagangan RI).

Maksud dan tujuan diadakannya kegiatan Sekolah Kader ini adalah untuk membekali calon-calon pengurus Partai NasDem agar lebih memahami tentang ke-NasDem-an, misi restorasi partai, serta tata kelola organisasi. Disadari, bahwa NasDem belum banyak memiliki konsepsi detail tentang berbagai hal yang dibutuhkan partai, salah satunya adalah sistem kaderisasi yang masuk dalam satu kesatuan sistem kepartaian yang diproyeksikan untuk mencetak kader-kader partai yang disiplin, berintegritas mulia, mampu dan cakap dalam menjalankan tugas kepartaian, serta loyal terhadap partai dalam rangka membangun masyarakat yang demokratis, berkeadilan, dan berkedaulatan. Nico Ainul Yakin, wakil ketua OKK DPW Partai NasDem Jawa Timur, mengatakan bahwa Sekolah Kader diproyeksikan untuk membuka peluang kader-kader terutama pengurus untuk memahami bagaimana sebuah organisasi dikelola dengan baik. Sekolah Kader biasanya dilaksanakan pada Bimtek (bimbingan teknis), yaitu semacam pembekalan yang berisikan materi-materi tentang kedewanan. ${ }^{18}$

17 Muzammil Syafi'i, Wawancara, 12 September 2016 di kantor DPW Partai NasDem Jawa Timur.

${ }^{18}$ Nico Ainul Yakin, Wawancara, 9 April 2017 pukul 15.00 WIB di Surabaya. 


\section{Peringatan Hari-Hari Besar Agama}

Kegiatan ini diselenggarakan setiap tahun. Salah satu kegiatan yang pernah diselenggarakan adalah Halaqah Hijrah yang bertajuk Hikmah Hijrah untuk Restorasi Indonesia, yang menghadirkan Hasyim Muzadi, mantan Ketua Umum PBNU sekaligus Dewan Pertimbangan Presiden (Wantimpres) era Jokowi-JK. Dalam kegiatan tersebut, Muzadi menyebut NasDem sebagai partai dengan karakter yang kuat. Tema restorasi-gerakan perubahan yang diusungnya merupakan watak NasDem untuk melakukan perubahan lebih radikal terhadap negara, pemerintah, dan partai.

Kegiatan lainnya adalah Halal bi Halal. Penyelenggaraan kegiatan ini juga dijadikan sebagai agenda tahunan, dan biasanya diselenggarakan setelah Hari Raya Idul Fitri. Kegiatan ini menjadi momentum yang diamini oleh umat Islam untuk saling bermaafan setelah sebulan penuh menunaikan ibadah puasa. Program Halal bi Halal ini dilaksanakan oleh NasDem Jawa Timur dalam bentuk silaturahim antara pengurus DPW dan DPD se-Jawa Timur yang kemudian ditindak-lanjuti oleh pengurus DPD dengan melibatkan pengurus DPC dan Ranting. Bukan hanya kegiatan besar agama Islam saja, kegaiatan besar keagamaan lainnya juga dilakakukan, seperti hari besar agama kristen, dalam hal ini Perayaan Natal dan Kenaikan Isa al-Masih.

4. Ramadan Mubarak (Kegiatan Ramadan)

Pada setiap bulan Ramaḍan, DPW NasDem Jawa Timur mengadakan serangkaian kegiatan, antara lain: (a) membagi takjil; (b) buka bersama; (c) tarawih dan tadarus; (d) Halaqah Ramadan. Dalam pembagian takjil, DPW menyiapkan sebanyak 500 bingkisan setiap hari yang dibagikan ke para pengguna jalan yang melintas di Jl. RA. Kartini 88 Surabaya (depan kantor NasDem Jawa Timur). Kegiatan bagi takjil ini berlangsung selama satu bulan penuh. Sementara kegiatan buka bersama, lazimnya dilakukan di internal pengurus DPW dan DPD-DPD se-Jawa Timur. Sedangkan untuk kegiatan tarawih dan tadarus diselenggarakan setiap malam di musala DPW yang diikuti oleh sebagian pengurus DPW, khususnya yang beragama Islam.

Pada sela-sela bulan Ramaḍan, DPW NasDem Jawa Timur juga mengadakan kegiatan Halaqah Ramadan. Salah satu kegiatan halaqah yang pernah digelar NasDem Jawa Timur, antara lain Halaqah Ramadan yang bertajuk Menggali Gagasan dan Ideologi Bung 
Karno dan Gus Dur (Perspektif Restorasi Indonesia). Kegiatan ini dihadiri oleh Bondan Gunawan (Mensesneg era Presiden Gus Dur), Munib Huda (Jubir Gus Dur), Hermawi Taslim (BAHU NasDem), dan Romo Didik. Hasil Halaqah ini dipublikasikan di Harian Kompas, ditulis oleh Nico Ainul Yakin dalam bentuk opini berjudul "Bung Karno, Gus Dur dan Surya Paloh sebagai Mata Rantai". Opini ini juga telah dipublikasikan di beberapa media online.

5. Khatmil-Qur'an

Dalam catatan penulis, sejumlah kegiatan khataman al-Qur'ān yang diadakan terbilang cukup unik. Disebut unik karena penyelenggaraannya dilaksanakan dalam perjalanan dengan naik bus. NasDem Jawa Timur setidaknya telah mengadakan kegiatan Khatmil-Qur'an on the Road sebanyak dua kali. Kegiatan yang pertama adalah di era kepemimpinan Choirie. Pada saat itu, sejumlah pengurus DPW dan sebanyak sembilan huffäa menjadi peserta dalam kegiatan ini. Mereka berkeliling ke sejumlah daerah di Jawa Timur sambil mengkhatamkan al-Qur'ān. Ada 11 daerah yang menjadi titik singgah, yaitu Lamongan, Tuban, Bangkalan, Kabupaten Malang, Probolinggo, Jember, Banyuwangi, Kediri, Ponorogo, Madiun, dan Surabaya. ${ }^{19}$ Selama perjalanan tersebut, paserta mampu menyelesaikan 11 kali khataman.

Kegiatan khataman yang kedua adalah pada era kepemimpinan Rendra Kresna. Kegiatan Khatmil-Qur'an di era Kresna memiliki corak yang sama dengan era Choirie. Pelaksanaannya sama-sama dilakukan sambil berkendara, perbedaannya terletak pada titik-titik singgahnya saja. Jika di era Choirie titik singgahnya di kantorkantor DPD Partai NasDem, maka di era Kresna adalah di pesantren-pesantren. Sejumlah pesantren yang dijadikan sebagai titik singgah, yaitu Pondok Pesantren (Ponpes) Langitan Tuban, Ponpes Tebuireng Jombang, Ponpes Al-Hikam Malang, Ponpes Al-Qodiri Jember, dan Ponpes Syaikhona Mochammad Kholil Bangkalan. Di tempat-tempat yang disinggahi itu, peserta berkesempatan bersilaturahim dengan pengasuh pesantren, sekaligus sebagai momentum untuk menerima masukan dan saran para ulama terkait dinamika bangsa dan negara, serta perjuangan

\footnotetext{
19 Tempat persinggahan di setiap daerah adalah kantor DPD Partai NasDem setempat. Adi Tirmidzi, Wawancara, 5 Januari 2017. Tirmizi adalah Ketua Panitia Khatmil-Qur'an on the Road DPW Partai NasDem .
} 
NasDem ke depan. Selain itu, di beberapa tempat yang disinggahi tersebut, peserta Khatmil-Qur'an menyempatkan ziarah. Di Tebuireng Jombang, perserta berziarah ke makam Gus Dur dan pendiri Ponpes Tebuireng. Sedangkan di Bangkalan, peserta berziarah ke makam Syaikhona Mochammad Kholil di Martajasah, Bangkalan. Selama perjalanan, peserta mampu menyelesaikan lima kali khataman.

6. Halaqah Restorasi Indonesia

Yakin mengatakan bahwa pada 4 Juli 2015, NasDem Jawa Timur menggelar Halaqah Ramaḍan bertajuk Menggali Ideologi dan Gagasan Bung Karno dan Gus Dur (Perspektif Restorasi Indonesia). Acara yang digelar di aula DPW NasDem Jawa Timur Jl. RA. Kartini 88 Surabaya tersebut dihadiri sekitar 300 kader NasDem dengan pembicara (1) Wakil Gubernur Jawa Timur Saifullah Yusuf, (2) Bondan Gunawan, Soekarnois dan mantan Mensesneg era pemerintahan Gus Dur, (3) Hermawi Fransiskus Taslim, sahabat Gus Dur sekaligus Ketua Umum Perhimpunan Mahasiswa Katolik Indonesia/Wakil Ketua Badan Advokasi Hukum Partai NasDem, (4) Romo Tri Budi Utomo Pr, Vikaril Jenderal Keuskupan Surabaya, (5) Munif Huda, mantan sekretaris pribadi Gus Dur, dengan moderator Tri Agung Tristanto, redaktur senior Harian Kompas. ${ }^{20}$

Dalam pengantar halaqah, Ketua DPW Partai NasDem Jawa Timur, waktu itu adalah Choirie, mengatakan bahwa NasDem sebagai partai baru dengan membawa misi Restorasi Gerakan Perubahan Indonesia, harus berbeda dengan partai lain yang sudah tua. Salah satu pembedanya adalah NasDem harus secara terusmenerus menggali ideologi, gagasan, dan pemikiran besar para pendiri dan pemimpin negeri ini. ${ }^{21}$ Khusus di Jawa Timur, menurut Choirie, hukumnya adalah wajib bagi NasDem untuk menggali pikiran Bung Karno, Gus Dur, bahkan HOS Tjokroaminoto dan pemimpin besar lain yang lahir di Jawa Timur. Hal ini penting, selain untuk memperkaya khazanah dan perspektif kader NasDem dalam menjalankan misi restorasi, pun menjadi inspirasi untuk langkah selanjutnya. Artinya, NasDem tidak boleh lepas dari sejarah dan akar kulturalnya, sehingga ia tidak terjebak pada rutinitas dan pragmatisme kekuasaan dan uang.

\footnotetext{
${ }^{20}$ Hasil obsevasi pada Orasi Politik Effendy Choirie pada 4 Juli 2015.

${ }^{21}$ Dokumentasi Orasi Politik Nico Ainul Yakin pada 4 Juli 2015.
} 
Dalam konteks inilah NasDem memulai tradisi intelektual melalui kajian terhadap gagasan, idelologi, dan pemikiran Bung Karno dan Gus Dur. Hal tersebut cukup menarik untuk dibahas mengingat keduanya merupakan tokoh besar yang pernah memimpin negeri ini dengan tradisi kepemimpinan yang visioner dalam konteks kehidupan bermasyarakat, berbangsa, dan bernegara. Meskipun kedua pemimpin itu telah tiada, tetapi ideologi dan gagasan-gagasannya sangat universal dan masih sesuai dengan dinamika kehidupan kekinian dan keakanan.

Beberapa varian pendidikan NasDem di atas tentu memiliki tujuan masing-masing. Namun, secera keseluruhan, tujuannya adalah sebagai jalan pembentukan religiusitas agensinya. Baik yang bersifat formal, nonformal, maupun informalnya, proses pendidikan yang tidak hanya sebagai upaya sosialisasi ideologi partai, tetapi juga sebagai wadah penyaluran dan pengembangan gagasan kader yang sesuai dengan cita-cita dan harapan partai sejak awal. Pada konteks inilah, varian-varian pendidikan tersebut dapat dilihat sebagai upaya strukturasi politik yang diharapkan dapat membentuk iklim politik atau budaya tertentu yang telah dirumuskan. Dengan kata lain, ragam pendidikan yang diadakan adalah komponen pembentukan nilai fundamental politik atau budaya tertentu.

\section{Orientasi Pendidikan Politik NasDem}

Berdasarkan beberapa varian yang dijelaskan di atas, nampak beberapa macam kategori proses pendidikan agen yang dilaksanakan oleh NasDem Jawa Timur, yakni pendidikan formal, non-formal dan informal, yang masing-masing memiliki orientasi tersendiri. Orientasi pendidikan politik tersebut sangat berkaitan dengan isi meteri atau acara dalam tiap-tiap proses pendidikan yang dilaksanakan. Beberapa penjelasan sebelumnya menyatakan bahwa ada dua inti materi yang disajikan dalam pendidikan yang dilaksanakan, yakni materi kepartaian dan kebangasaan. Isi materi kepartaian di antaranya adalah sejarah lahirnya Partai NasDem, pendiri, visi-misi, manifesto, garis politik, dan ideologi. Sedangakan di antara isi materi kebangsaan adalah seluruh pengetahuan tentang falsafah negara dan kitab konstitusinya.

Selain kedua pemahaman ini (kepartaian dan kebangsaan), nampak pula adanya pemahaman lain yang diupayakan guna membentuk tindakan agen. Hal ini terlihat dengan adanya kegiatan- 
kegiatan keagamaan yang diadakan oleh NasDem Jawa Timur. Sebagaimana dipahami, adanya kegiatan keagamaan ini juga memiliki orientasi tertentu, yaitu untuk memberikan suntikan unsur religius dalam pendidikan politik. Masuknya unsur religi tersebut, salah satunya yang terpenting, adalah untuk membangun persepsi bahwa NasDem bukanlah partai nasionalis-sekuler, tetapi sebaliknya sebagai partai nasionalis-religius. ${ }^{22}$

Selain itu, berdasarkan beberapa wawancara yang dilakukan, kegiatan-kegiatan keagamaan juga dijadikan jalan penanaman nilai luhur agama yang dapat ikut serta membentuk keluhuran tindakan politik masing-masing agen partai. Dengan demikian, dalam konteks pendidikan politik NasDem, pendidikan yang dilakukan bukan saja merupakan upaya transfer pengetahuan (transfer of knowledge), tetapi lebih dari itu juga upaya transfer nilai (transfer of value). Artinya, seluruh pembelajaran yang dilakukan bukan hanya berorientasi menciptakan pemahaman saja, tetepi juga berorientasi pada terbentuknya nilai tindakan agen NasDem. ${ }^{23}$

Orientasi transfer pengetahuan dan nilai tersebut mengindikasikan adanya proses pembelajaran sekaligus doktrinasi pada proses pendidikan NasDem. Ada upaya pengintegrasian penanaman nilai-nilai dan pengetahuan politik yang harus ada dalam diri kader partai. Yang demikian ini dapat disebut juga sebagai upaya pewarisan NasDemologi. ${ }^{24}$ Jadi, penekanan orientasi pelatihan sebagaimana yang dijelaskan sebelumnya adalah terbentuknya kader yang unggul baik pengetahuan dan moralitasnya. Pada sisi ini, pendidikan politik yang ada di NasDem merupakan hal yang disebut David Easton dan Jack Dennis sebagai development process which persons acquire orientation and patterns of bebaviour. $^{25}$ Secara lebih detail, gambaran mengenai varian-varian pendidikan politik NasDem baik dalam bentuknya yang formal, non-formal, dan informal, di antaranya adalah Sekolah Legislatif,

\footnotetext{
22 Zulfikar, Ketua DPD NasDem kota Probolinggo sekaligus Wakil Ketua DPRD Kota Lumajang, dalam Wawancara, 14 April 2017.

23 Pandangan pendidikan sebagai transfer nilai adalah pandangan terkait pendidikan agama. Muhaimin, Paradigma Pendidikan Agama Islam (Bandung: PT Remaja Rosdakarya, 2002), 75.

24 NasDemologi adalah sebutan penulis pada nilai dan pengetahuan politik NasDem yang diajarkan pada setiap kader partainya.

${ }^{25}$ David Easton and Jack Dennis, Children in the Political System: Origins of Political Legitimacy (New York: McGraw-Hill, 1969), 95.
} 
peringatan hari-hari besar agama, Ramadan Mubarak (Kegiatan Ramadan), Khatmil-Qur'an, Halaqah Restorasi Indonesia. Dengan demikian, orientasi penyelenggaraan pendidikan NasDem sudah terbilang ideal. Hal ini sesuai dengan pengertian Alfian bahwa pendidikan politik merupakan upaya sadar proses sosialisasi politik pada masyarakat guna memahami dan menghayati betul nilai-nilai yang terkandung dalam sistem politik yang ideal yang hendak dibangun. ${ }^{26}$

Pada aspek transfer pengetahuan, jelas bahwa pemahaman yang berusaha diajarkan dalam pendidikan politik NasDem adalah pemahaman kepartaian, kebangsaan, dan keagamaan. Sementara untuk mengetahui aspek transfer nilai, harus diperas lebih dahulu nilai-nilai yang ada dalam content ketiga materi tersebut. Pada materi kepartaian, kader diajarkan tentang pemahaman bahwa NasDem sangat peduli pada rakyat kecil dan memiliki misi restorasi Indonesia baru yang sejahtera. Kesejahteraan yang dimaksud adalah kemakmuran rakyat Indonesia. Di sini, tampak bahwa nilai yang ingin ditanamkan adalah humanis. Nilai humanis ini nampaknya juga terlihat pada aspek materi kebangsaan. Baik materi tentang fasafah Pancasila, UUD, dan lainnya, terlihat sebagai upaya penanaman prinsip kemanusia yang adil dan beradab bagi seluruh rakyat Indonesia. Sedangkan kegiatan keagamaan merupakan isyarat bahwa NasDem juga berusaha mengambil intisari nilai keagamaan untuk memperkokoh nilai yang ada pada kedua materi sebelumnya. Adanya kegiatan keagamaan dijadikan sebagai media internalisasi nilai religius. Sampai di sini, terdapat dua orientasi nilai yang ditanamkan dalam pendidikan politik NasDem, yakni humanis dan religius.

Selanjutnya, kedua nilai inilah yang menurut Choirie menjadi unsur vital untuk memenuhi cita-cita berupa komitmen NasDem Jawa Timur. $^{27}$ Sebagaimana dikemukakan di awal, bahwa pada hakikatnya seluruh proses pendidikan yang diadakan oleh NasDem Jawa Timur adalah guna membangun peradaban agensi yang lebih baik. Seluruh materi yang ada adalah untuk membentuk nilai fundamental pada budaya gerakan politik NasDem sendiri. Seluruh

\footnotetext{
${ }^{26}$ Alfian, Pemikiran dan Perubahan Politik Indonesia; Kumpulan Karangan (Jakarta: PT Gramedia, 1981), 235.

27 Observasi pada Sekolah Kader DPD Partai NasDem Kabupaten Sidoarjo di The Sun Hotel, 24 April 2016.
} 
materi dan pengetahuan yang diberikan mengarah pada satu tujuan yang dicita-citakan. Beberapa penjelasan di atas secara ringkas digambarkan dalam bagan berikut:

Bagan 1:

Pendidikan Politik Partai NasDem dan Orientasinya

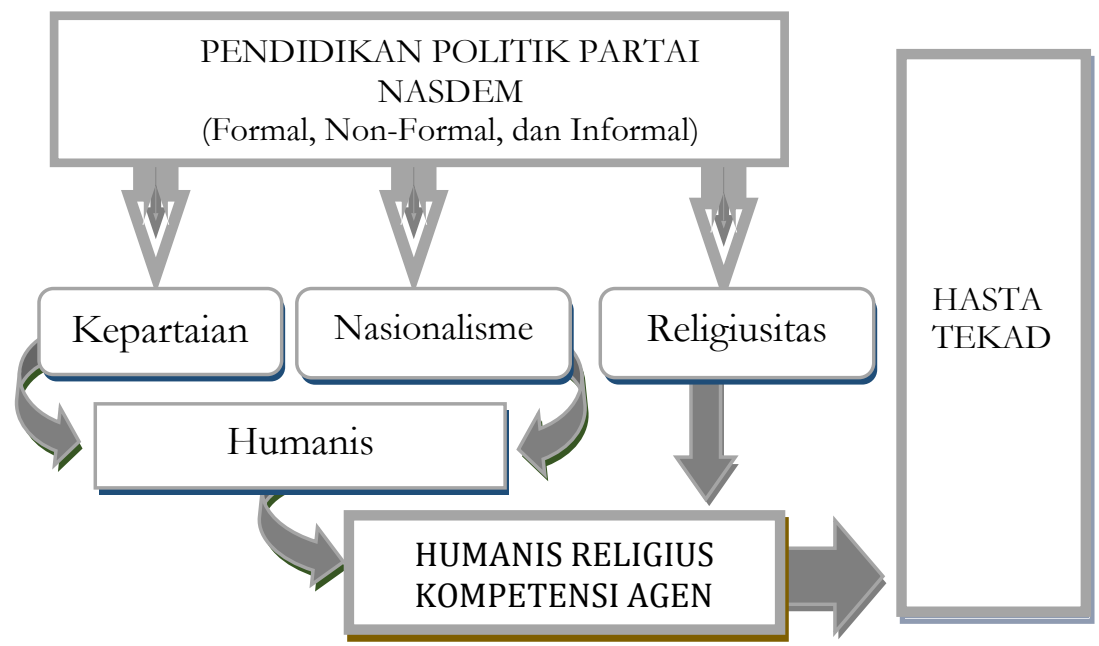

Berdasarkan bagan di atas, seluruh varian pendidikan politik NasDem bertujuan menguatkan tiga aspek penting, yakni pengetahuan "kepartaian", "nasionalisme", dan "relgiusitas". Materi kepartaian dan materi nasionalisme sebenarnya berisi tentang nilai-nilai kemanusian, sedangkan materi religiusitas menguatkan kesadaran agama. Berdasarkan hal ini dapat disimpulkan bahwa orientasi pendidikan politik NasDem secara umum adalah terciptanya nilai fundamental humanis-religius. Hal demikian inilah yang selanjutnya menjadi dasar rusumusan penyusunan arah gerakan NasDem Jawa Timur.

Susunan arah tersebut dikenal dengan nama "Hasta Tekad". Menurut Choirie, Hasta (Bahasa Sansekerta) berarti delapan. Tekad berarti kemauan (kehendak) yang pasti, kebulatan hati, iktikad (niat) yang bulat (KUBI). Adapun susunannya adalah sebagaimana berikut:

a) Mempertahankan dan melaksanakan Pancasila sebagai falsafah, azas, dan ideologi final bagi bangsa dan negara Indonesia;

b) Mempertahankan dan melaksanakan prinsip Bhinneka Tunggal Ika dan wawasan nusantara, serta menghormati lambang negara; 
c) Mempertahankan dan meneguhkan NKRI sebagai bentuk final negara Indonesia;

d) Melaksanakan UUD 1945 dan membangun kesadaran berkonstitusi bagi bangsa Indonesia;

e) Meneguhkan dan melestarikan bahasa Indonesia sebagai bahasa persatuan nasional serta menghormati seluruh produk budaya bangsa sebagai kekayaan nusantara;

f) Membangun budaya bersih dari korupsi, kolusi, dan nepotisme serta perbuatan tercela lainnya;

g) Tunduk dan patuh melaksanakan visi, misi, tujuan, dan seluruh kebijakan Partai NasDem melalui restorasi gerakan perubahan sebagai garis politiknya;

h) Selalu hadir membela dan memperjuangkan hak-hak dan kepentingan rakyat.

Beberapa hal di atas dicanangkan sebagai nilai fundamental gerakan politik yang diharapkan oleh NasDem Jawa Timur. Jika ditelisik secara mendalam, Hasta Tekad merupakan tata formal arah gerakan yang ingin megintegrasikan nilai-nilai kemanusian dan keagamaan. Keduanya tentu merupakan nilai yang dewasa ini sangat diperlukan dalam kehidupan politik. Sebagaimana mafhum, hanya dengan kedua nilai tersebutlah para aktor politik akan bergerak bersama untuk kemaslahatan umat yang memiliki semangat keagamaan yang tinggi.

\section{Dimensi Agama dalam Pendidikan Politik}

Dalam bukunya yang berjudul The Social Interpretation of Religion, Roland Robertson mengemukakan bahwa dalam kegiatan sosialkeagamaan terdapat dua dimensi, yakni nominal (nominal definition) dan riil (real definition). ${ }^{28}$ Demensi nominal agama adalah menjelaskan agama sebagai media interaksi Tuhan dan hambanya. Agama dianggap sebagai kumpulan ritual dengan sifat manifest praktis berupa kegiatan atau tindakan yang merupakan bentuk komunikasi vertikal antara makhluk dan Tuhannya. Sebaliknya, dimensi riil agama merupakan penjelasan agama yang memiliki implementasi riil sosiologis sebagai seperangkat aturan tindakan moral dan etis kehidupan sosial yang empiris.

\footnotetext{
${ }^{28}$ Roland Robertson, The Social Interpretation of Religion (Oxford: Brasil Blackwell, 1972), 33.
} 
Berdasarkan penjelasan di atas, dimensi agama yang ada di NasDem Jawa Timur dapat digolongkan menjadi dua varian besar, yakni dimensi ritual-simbolik dan dimensi substantif. Dimensi ritual-simbolik mengajarkan nilai-nilai keagamaan yang sejalan dengan nilai-nilai keadaban modern seperti sikap rasional, militan, disiplin dan bertanggungjawab, terbuka, memperjuangkan aspirasi publik, memihak kepentingan rakyat, berpolitik tanpa mahar, berakhlak mulia, dan selalu ikhlas. Pada dimensi ini, NasDem Jawa Timur mengupayakan penyelenggaraan keagamaan yang sifatnya ritual. Ritual tersebut berbentuk kegiatan keagamaan yang biasa dilaksanakan oleh kelompok agama (dalam hal ini kelompok Islam dan Kristen). Kegiatan seperti sarwaan, tablilan, maulidan, kenaikan Isa al-Masih dan Perayaan Natal adalah pendidikan agama yang memiliki dimensi ritual-simbolik.

Adapun dimensi substanstif yang dimaksud di sini adalah pemberlakuan intisari ajaran agama yang bermuara pada nilai moralitas kehidupan sosial. Nilai substantif agama merupakan perasaan dari sebuah anggapan bahwa agama memiliki peran bumanity value control. Peran agama pada konteks ini dipandang sebagai sistem nilai yang ada dalam kebudayaan manusia dan menjadi pendorong, penggerak, dan pengontrol tindakan moral manusia sehingga tidak menyimpang dari norma kemanusiannya sendiri. ${ }^{29}$ NasDem memantapkan tekad untuk mengusung semangat restorasi berdasarkan nilai-nilai substantif agama. Beberapa kegiatan pendidikan politik agen selalu dibangun dengan motivasi teologis. Dimensi agama substantif senantiasa diupayakan guna memberikan semangat hidup para agen partai, sehingga kepercayaan akan agama tidak membuat mereka teralienasi sebagaimana anggapan Marx tentang agama. ${ }^{30}$ Nilai agama secara substantif dalam NasDem berperan sebagai motivasi sebagaimana pandangan Ishomuddin yang secara komprehensif telah menjelaskan fungsi agama dalam kehidupan sosial. ${ }^{31}$

\footnotetext{
29 Muhammad In'am Esha, Teologi Islam: Isu-Isu Kontemporer (Malang: UIN Malang Press, 2008), 37.

30 Menurut Marx, semakin manusia menyifati dirinya dengan Tuhan, dia tidak akan mempunyai kehidupan dalam dirinya. Rober C. Tucker (ed.), The MarxEngels Reader (New York: Norton Company, 1978), 71.

31 Ishomuddin, Pengantar Sosiologi Agama (Jakarta: PT. Ghalia Indonesia-UMM Press, 2002), 53.
} 
Pada intinya, adanya dimensi religius-substatif dalam pendidikan NasDem adalah untuk lebih menguatkan dimensi keagamaan partai. Artinya, religiusitas tidak hanya menunjukkan dimensi simboliknya saja, akan tetapi lebih dari itu, menunjukkan pengutan terhadap nilai substantifnya. Sebagaimana dikatakan oleh Kresna, bahwa religiusitas NasDem bukanlah religius-simbolik. Atribut-atribut atau simbol-simbol keagamaan tidak dibawa ke ranah politik, karena religiusitasnya menjelma secara substantif dalam aktivitas politik. Nasionalisme-religius sebagai cita-cita NasDem menjadi tuntutan untuk mengakui kebhinnekaan bangsa. Bangsa yang majemuk baik suku, agama, ras, dan aliran menempatkan nasionalisme sebagai arah ideologis bangsa yang plural. Agama menjadi bagian dari kebangsaan dan kerakyatan. Dengan demikian, nasionalisme-religius harus terpatri serta inheren pada diri kader-kader NasDem.

Selain itu, sebagaimana disebutkan di awal, nilai religiussubstantif ini juga sangat tepat jika dikontekstualisasikan pada keadaan perpolitikan dewasa ini. Dalam kajiannya, Max Weber menyebutkan adanya pengaruh nilai-nilai agama terhadap perilaku agen ekonomi. Dalam bukunya yang terkenal, The Protestant Ethic and the Spirit of Capitalism, Weber berusaha menjelaskan mengapa kapitalisme modern berkembang di Eropa Barat dan Amerika, dan tidak berkembang di wilayah lainnya. ${ }^{32}$ Dalam penjelasannya dinyatakan bahwa suatu kegiatan unik yang bersifat keagamaan, yaitu reformasi Protestan (Calvinism), telah melahirkan nilai-nilai baru secara mendasar, yang memberikan pengesahan kepada usaha-usaha yang bercorak ekonomi. ${ }^{33}$

Transformasi nilai agama yang substansif menjadi kunci jawaban bagi problem yang demikian ini. Strukturasi nilai substantif dapat secara masif mengubah peran agama menjadi lebih humanis. Daniel L. Pas yang mengembangkan pemikiran Emile Durkheim mengatakan bahwa moralitas, agama, dan realitas tidak bisa dipisahkan. Masing-masing memiliki hubungan yang dependen. Keyakinan beragama akan secara penuh mengatur pandangan moral dalam realitas kehidupan masyarakat. Dengan

\footnotetext{
32 Max Weber, Etika Protestan dan Semangat Kapitalisme, terj. TW. Utomo \& Yusup Pria Sudiarja (Yogyakarta: Pustaka Pelajar, 2006), 65-66.

33 Ajat Sudrajat, Etika Protestan dan Kapitalisme Barat: Relevansinya dengan Islam di Indonesia (Jakarta: Bumi Aksara, 1997), 1-11.
} 
demikian, NasDem yang menghubungkan ketiganya, sangat tepat untuk menjawab problematika perpolitikan dewasa ini. ${ }^{34}$ NasDem mengupayakan perasan nilai substantif pada nilai-nilai kebangsaan. Ia berupaya mensinergikan rụ̄ al-watanìah dan rụh al-dinìyah. Dimensi religius-substantif sangat selaras dengan falsafah bangsa ini, sebagaimana hal ini dirasakan oleh beberapa agen penggerak NasDem. ${ }^{35}$

Konklusi dari beberapa kajian di atas dapat dinyakan bahwa kedua dimensi yang ada tersebut memiliki peran masing-masing, saling berhubungan, dan berjalan selaras. Dimensi ritual diorientasikan untuk penguatan hubungan vertikal manusia dengan tujuan meningkatkan spiritualitas keagaman, sedangkan dimensi substantif diorientasikan pada kesalehan kehidupan sosial agen partai, terutama dalam skala kehidupan sosial-politik.

\section{Orientasi Pembentukan Agency}

Pembentukan tindakan agen yang dimaksud di sini terkait dengan bagaimana dimensi religiusitas memberikan pengetahuan dan pengalaman pada agen, dengan tujuan membentuk rasionalitas dalam tindakannya. Dua dimensi yang disebutkan sebelumnya memiliki orientasi khusus dalam membentuk rasionalitas para agen NasDem. Kondisi ini mengisyaratkan bahwa budaya politik religius dibentuk dan dikembangkan oleh pelaku politik, dan apa yang akan

\footnotetext{
${ }^{34}$ Daniel L. Pals, Eight Theories of Religion (New York: Oxford University Press, 2006), 91-92.

35 Dalam pengantar bukunya dokumentasi NasDem, Choirie menyatakan bahwa banyak orang bertanya mengapa ia hijrah bukan ke partai Islam seperti PPP, tapi justru ke partai nasionalis yang pendirinya bukan orang NU dan bukan aktivis gerakan keagamaan seperti latar belakang dirinya. Diakuinya, hal tersebut tak bisa dilepaskan dari masa saat ia masih aktif di PMII, bergaul dengan temantemannya dari PMKRI, GMNI, GMKI, HMI dan lainnya. Pada masa itulah awal ia merasakan nikmatnya keberagaman. Selain itu, dinyatakan bahwa ia juga pernah nyantri kepada Gus Dur yang perilaku dan visi politiknya amat pluralis dan nasionalistis, yang kelak membuat dirinya nyaman berada di lingkungan manapun. Apalagi, ajaran pendiri NU, KH. Hasyim Asy'ari, tidak pernah mempertentangkan antara kebangsaan dan ke-Islaman. Menurut Kiai Hasyim, agama dan nasionalisme adalah dua kutub yang tidak berseberangan. Nasionalisme adalah bagian dari agama, dan keduanya saling menguatkan. Dari sini pula muncul pemikiran-pemikiran tentang pentingnya sebuah bangsa dan negara. Kiai Hasyim menyatakan bahwa setiap anak bangsa Indonesia wajib mencintai tanah air (bubb al-watan min al-imān). Observasi pada "Kata Pengantar" Effendy Choirie dalam buku dokumentasi NasDem.
} 
ditentukan oleh pelaku politik tersebut, sebagai ciri-ciri utama budaya politik mereka, sampai batas tertentu dipengaruhi oleh pendidikan mereka. Hubungan antara budaya politik dan pendidikan bersifat tidak langsung. Hal ini berarti pendidikan tidak serta-merta membentuk pelaku politik secara sempurna sekaligus. Pendidikan memberikan dasar-dasar kepada tiap calon pelaku politik. Jika dasar-dasar ini baik dan kokoh, maka kemungkinan lahirnya pelaku-pelaku politik yang baik sangatlah besar. Sebaliknya, jika dasar-dasar yang diberikan oleh pendidikan jelek dan rapuh, kemungkinan besarnya ialah munculnya pelaku-pelaku politik yang jelek dan rapuh pula di kemudian hari.

Dimensi religius digunakan oleh NasDem sebagai penguatan kesadaran para agen. Hal ini berkesesuaian dengan apa yang dikatakan oleh Giddens, bahwa tindakan agen berbasis pada tiga kesadaran, yang ketiganya dapat diperkuat melalui penguatan dimensi religiusitas baik yang berhubungan dengan sisi spiritual maupun praksis. Dengan tindakan yang tercipta secara simultan, menurut Giddens, kemudian agen dapat mereproduksi tindakan yang baru untuk dikembangkan. ${ }^{36}$ Guna kepentingan pembahasan yang rinci dan sistematis, pada bagian ini akan coba digambarkan dan dijelaskan satu-persatu orientasi dimensi religius yang bersifat ritual-simbolik maupun substantif dari pendidikan politik NasDem, yang keduanya saling berhubungan dalam menciptakan kesadaran bagi tindakan agen.

Pertama, dimensi ritual-simbolik tampak ditujukan pada penguatan landasan spiritual partai. Yang demikian ini berkenaan dengan peningkatan keimanan agen pada Tuhan Yang Maha Esa dan peneguhan ajaran agama sebagai basis perjuangan. Pendidikan keagamaan yang berbentuk ritual hendak meneguhkan pondasi keimanan sebagai awal pemahaman agen dalam bertindak. Dalam dimensi ini, perilaku politik partai yang berbentuk ritual diorientasikan sebagai simbol penekanan pada keterhubungan antara kesadaran agama dalam politik. Artinya, melalui ritualsimbolik keagamaan, NasDem ingin menciptakan pemahaman bersama terkait dengan hubungan agama dan politik.

\footnotetext{
${ }^{36}$ John B. Thompson, Analisis Ideologi; Kritik Wacana Ideologi-ideologi Dunia, terj. Haqqul Yakin (Yogyakarta: Ircisod, 2003), 241.
} 
Kedua, dimensi religiusitas yang substantif nampak pada upayaupaya NasDem yang berorientasi pada penguatan nilai-nilai universalisme agama dalam memberikan kesadaran pada agennya. Hal ini terlihat dari beberapa temuan yang didapat baik melalui wawancara yang dilakukan maupun dalam observasi di beberapa acara kepartaian NasDem. Dalam hal ini, upaya pembentukan kesadaran tindakan adalah melalui penyerapan nilai antroposentrisme keagamaan yang lebih universal sebagai rahmat bagi seluruh alam. Pembentukan nilai religius-substantif dipandang sebagai salah satu cara terbaik untuk menguatkan kesadaran tindakan politik agen partai. Melalui nilai ini, jiwa agen mendapatkan standar pemahaman moralitas yang mapan dalam memproduksi tindakannya. ${ }^{37}$

Sementara itu, NasDem Jawa Timur mengupayakan terbentuknya kesadaran yang lahir dari substansi ajaran agama pada diri agen lewat dua hal berikut:

1. Membentuk karakter humanis agen. Hal ini merupakan upaya sublimasi nilai pengabdian agama pada masyarakat; yaitu penjelmaan nilai religius ke dalam visi kebangsaan NasDem, baik berupa aktivitas 'ibädah mạ̣dah dan ghayr maḅdah. Kegiatan ritual peribadatan kader menjadikan masyarakat sebagai sejadah perjuangan. $^{38}$

2. Kesadaran urgensi amanah dan keadilan tindakan agen. Pada orientasi ini, NasDem mengupayakan tindakan agen didasarkan pada kepercayaan bahwa semua apa yang dilakukan adalah amanah yang harus dilaksanakan. Orientasi ini serta merta akan menguatkan komitmen tindakan agen yang bertanggungjawab dan transparan. Rasa amanah ini pun juga akan mendorong kader untuk selalu bersikap adil.

\footnotetext{
37 Nilai substansif memberikan kesan dan menciptakan standar moral kader. Nilai ini tidak dapat dicerna oleh akal budi atau logika manusia. Namun, menurut Soeitoe, mengatakan akan mempengaruhi jalan pikiran yang rasional. Samuel Soeitoe, Psikologi Pendidikan untuk Para Pendidik dan Calon Pendidik (Jakarta: Lembaga Penerbit Fakultas Ekonomi Universitas Indonesia, 1982), 87. 38 Observasi pada Konsolidasi Partai NasDem , pada bulan Ramaḍan, 19 Juli 2015.
} 
Seorang kader partai dilarang keras masuk atau bergabung ke partai hanya semata mencari elektabilitas, popularitas, ataupun kekuasaan. Tujuan untuk beribadah juga menjadi hal penting yang terpatri kuat pada diri kader. Nilai-nilai religius, termasuk dalam hal ini keikhlasan, pengorbanan, kesetiakawanan, dan selalu menolong dalam kebajikan selalu ditekankan dan harus memancar pada diri kader NasDem. Dengan demikian, kader diharapkan memiliki amanah dan sikap adil dalam politik, terutama ketika menjadi pemimpin. Terkait religiusitas partai ini juga dinyatakan oleh Choirie, bahwa keadilan menjadi poin penting NasDem dalam memperjuangkan hak-hak kebangsaan. Semua pihak berkewajiban menjunjung keadilan, sebab menurutnya, keadilan adalah bagian dari ajaran agama. Tidak ada alasan bagi pemeluk agama untuk tidak memperjuangkan keadilan. Politik hanyalah alat atau media untuk memperjuangkan keadilan tersebut; politik adalah salah satu jalan dalam menegakkan ajaran agama.

Seluruh kegiatan NasDem berdimensi ibadah. Artinya, apa yang dilakukan oleh pengurus dan kader akan dipertanggungjawabkan pada Allah. Oleh karena itu, 'ibadah politik' tersebut harus dilandasi keikhlasan, karena ibadah tanpa keikhlasan akan sia-sia. Manusia akan rusak kecuali yang berilmu; yang berilmu akan rusak kecuali yang diamalkan; bahkan ilmu pengetahuan juga akan rusak kecuali yang dilandasi keikhlasan. Hal tersebut penting mengingat manusia pada hakikatnya cenderung mempertimbangkan untung-rugi dalam bertindak. ${ }^{39}$ Menurut al-Qardāwī, manusia perlu memperhatikan urgensi internalisasi ikhlas dalam dirinya. ${ }^{40}$ Pada titik ini, kader NasDem yang bergerak di garda depan pembangunan bangsa harus membawa nilai-nilai religius ke dalam perjuangannya. Kader tidak hanya fokus pada perebutan kursi kekuasaan, tetapi lebih dari itu harus mampu membawa nilai-nilai perubahan ke dalam ruang kehidupan. Oleh karena itu, sekolahsekolah atau pendidikan yang ada di NasDem sarat akan penyampaian nilai-nilai yang harus diunggah ke dalam praktik politik yang ada.

\footnotetext{
39 Shofaussamawati, Ikblas Perspektif al-Quran: Kajian Tafsir Maudbu’i (t.t.: STAIN Kudus, 2013), 331.

40 Yūsuf al-Qarḍāwī, Niat dan Ikhlas (Jakarta: Pustaka al-Kautsar, 1996), 22.
} 
Bagan 2:

Orientasi Dimensi Religiusitas Agensi Pendidikan Politik

NasDem

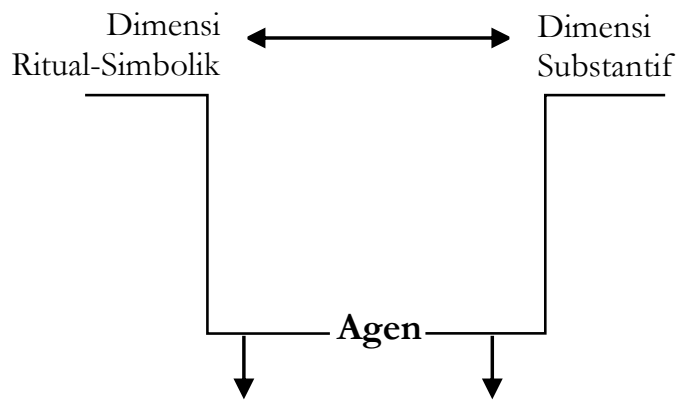

(1) Penguatan Keimanan;

(1) Membentuk karakter

(2) terciptanya pemahaman humanis agen; (2) kesadaran

dan kesadaran Agama yang terintegrasi dengan urgensi amanah dan keadilan tindakan agen kebangsaan

Kerangka konseptual pada bagan di atas menunjukkan bahwa seluruh dimensi religius yang diupayakan oleh NasDem Jawa Timur memiliki orientasi pembentukan kesadaran agennya. Seluruh agennya didorong agar mengembangkan kepercayaan agamanya sebagai dasar perjuangan dalam partai. Hal tersebut berorientasi pada terciptanya jiwa agen yang memiliki karakter saleh baik secara spiritual maupun sosial.

\section{Penutup}

Terdapat dua dimensi religiusitas yang ada dalam pendidikan politik NasDem Jawa Timur. Dimensi religiusitas yang pertama adalah yang bersifat ritual-simbolik sebagaimana yang terkandung dalam berbagai program dan kegiatan keagamaan yang diselenggarakan oleh NasDem. Sedangkan dimensi religiusitas yang kedua adalah bersifat substantif. Berbeda dengan dimensi yang bersifat ritual-simbolik, dimensi yang kedua ini berada pada materi dan plaform yang didengungkan.

Internalisasi kedua dimensi tersebut pada tindakan aktor begitu nampak. Dimensi ritual-simbolik nampak pada peningkatan keimanan dan persepsi bahwa kesadaran aktor politik NasDem tidak boleh sekuler dalam politik. Sedangkan dimensi substantifnya nampak pada upaya membentuk kesadaran tindakan aktor yang humanis, religius, dan amanah dalam setiap langkah perjuangannya; 
aktor dapat membawa ruh agamanya yang sifatnya teologis mejadi teoantroplogis.

\section{Daftar Rujukan}

\section{Buku dan Jurnal}

Alfian. Pemikiran dan Perubahan Politik Indonesia; Kumpulan Karangan. Jakarta: P'T Gramedia, 1981.

Beger, Peter L. Langit Suci: Agama sebagai Realitas Sosial, terj. Hartono. Jakarta: LP3ES, 1991.

Brownhill, Robert dan Patricia Smart. Political Education. London dan New York: Routledge, 1989.

Easton, David and Jack Dennis. Children in the Political System: Origins of Political Legitimacy. New York: McGraw-Hill, 1969.

Esha, Muhammad In'am. Teologi Islam: Isu-Isu Kontemporer. Malang: UIN Malang Press, 2008.

Hariyanti et al. "The Role of Political Parties in Building Loyalty Women Cadres through Political Education", Proceedings of the Annual Civic Education Converence (ACEC 2018).

Haryatmoko. "Menyingkap Kepalsuan Budaya Penguasa: Landasan Teoritis Gerakan Sosial Menurut Pierre Bourdieu”, Basis, Vol. 52, No. 11-12, 2003.

Ishomuddin. Pengantar Sosiologi Agama. Jakarta: PT. Ghalia Indonesia-UMM Press, 2002.

Machiavelli, Niccolo. Sang Penguasa: Surat Seorang Negarawan kepada Pemimpin Republik, terj. C. Woekirsari. Jakarta: Gramedia, 1987.

Muhaimin. Paradigma Pendidikan Agama Islam. Bandung: PT Remaja Rosdakarya, 2002.

Pals, Daniel L. Eight Theories of Religion. New York: Oxford University Press, 2006.

Panuju, Redi. "The Politicization of Religion, Ironi of Ideology and Clash of Discourse Approaching 2019 General Election”, Jurnal Penelitian, Vol. 15, No. 1, 2018.

Qarḍ̄w̄ī (al), Yūsuf. Niat dan Ikhlas. Jakarta: Pustaka al-Kautsar, 1996.

Robertson, Roland. The Social Interpretation of Religion. Oxford: Brasil Blackwell, 1972.

Shofaussamawati. Ikhlas Perspektif al-Quran: Kajian Tafsir Maudhu'i. T.t.: STAIN Kudus, 2013. 
Soeitoe, Samuel. Psikologi Pendidikan untuk Para Pendidik dan Calon

Pendidik. Jakarta: Lembaga Penerbit Fakultas Ekonomi Universitas Indonesia, 1982.

Sudrajat, Ajat. Etika Protestan dan Kapitalisme Barat: Relevansinya dengan Islam di Indonesia. Jakarta: Bumi Aksara, 1997.

Surbakti, Ramlan. Memahami Ilmu Politik. Jakarta: Grasindo, 2010.

Suryanef et al. "Political Education for Female Cadres as an Effort to Gender Equality in Politics", Proceedings of the 1st International Conference on Social Sciences and Interdisciplinary Studies (ICSSIS 2019).

Thompson, John B. Analisis Ideologi; Kritik Wacana Ideologi-ideologi Dunia, terj. Haqqul Yakin. Yogyakarta: Ircisod, 2003.

Tucker, Rober C. (ed.). The Marx-Engels Reader. New York: Norton Company, 1978.

Weber, Max. Etika Protestan dan Semangat Kapitalisme, terj. TW. Utomo \& Yusup Pria Sudiarja. Yogyakarta: Pustaka Pelajar, 2006.

Zulfikar, Ketua DPD NasDem kota Probolinggo sekaligus Wakil Ketua DPRD Kota Lumajang, dalam Wawancara, 14 April 2017.

\section{Wawancara}

Effendy Choirie. Wawancara. Minggu, 18 Maret 2017 pukul 08.00 WIB di Surabaya.

Muzammil Syafi'i. Wawancara. 13 Maret 2017 di kantor DPRD , Jl. Indrapura Jaya No. 1 Krembangan Selatan, Surabaya.

H. Achmad Heri. Wawancara. 22 Maret 2017 pukul 19.00 WIB di Surabaya.

Adi Tirmidzi. Wawancara. 5 Januari 2017.

Nico Ainul Yakin. Wawancara. 9 April 2017 pukul 15.00 WIB di Surabaya.

\section{Dokumentasi dan Observasi}

Dokumentasi Orasi Politik Effendy Choirie pada 4 Juli 2015.

Dokumentasi Orasi Politik Nico Ainul Yakin pada 4 Juli 2015.

Observasi "Kata Pengantar" Effendy Choirie dalam buku dokumentasi NasDem.

Observasi Sekolah Kader di Hotel Savana, Malang, 12-14 Juni 2014.

Observasi pada Konsolidasi Partai NasDem, pada bulan Ramaḍan, 19 Juli 2015. 
Luluk Mashluchah

Observasi pada Sekolah Kader DPD Partai NasDem Kabupaten Sidoarjo di The Sun Hotel, 24 April 2016. 